\title{
Emergence and control of gorse seedlings after the 2017 Port Hills fire
}

\author{
B.J.O. TAYLOR, K.M. POLLOCK and D.J. MOOT \\ Lincoln University, Field Research Centre, Faculty of Agriculture and Life Sciences \\ PO Box 85084, 7647, Lincoln, New Zealand \\ Derrick.Moot@lincoln.ac.nz
}

\begin{abstract}
An experiment on the Port Hills, Canterbury, after mature gorse was burnt in the fires of February 2017, showed an oversown Italian ryegrass mix out-competed the rapidly germinating gorse seedlings. The shaded gorse seedling population reached a peak of 680 plants/ $\mathrm{m}^{2}$ in June, declining to $\sim 450$ plants $/ \mathrm{m}^{2}$ in October compared with $>600$ plants $/ \mathrm{m}^{2}$ in the unshaded plots. As soil moisture dropped in summer, the gorse seedling population decreased to 10 plants $/ \mathrm{m}^{2}$ by March 2018, compared with 73 plants $/ \mathrm{m}^{2}$ in the unshaded plots. Gorse seedlings that had been shaded by Italian ryegrass had shorter roots and lower dry weights than those grown without competition. The oversown mix was more successful on the south than north-facing slope where more bare ground enabled patches of gorse to re-establish. The oversowing of Italian ryegrass was shown to be a viable option to control gorse particularly after an unplanned burn that removed the fences and water supply.
\end{abstract}

Keywords: aspect, Italian ryegrass, Lolium multiflorum, oversowing, Ulex europaeus

\section{Introduction}

On 13th February 2017, a major fire started in grasslands on the Port Hills near Christchurch. It ignited on Early Valley Road and swept uphill into the valley, burning vegetation and scattering livestock. A second fire started on Marleys Hill. Together they burnt 1645 ha of land, including a mature Pinus radiata forest, native bush, 11 houses, and two outbuildings. The major fuel source was dried-off seedheads and dead material from laxly grazed tall oat grass (Arrhenatherum elatius), browntop (Agrostis capillaris) and cocksfoot (Dactylis glomerata)-based pasture. This standing herbage of 5-6 t DM/ha had built up after a wet spring in 2016 that had encouraged pasture growth. This was followed by 3 months of below average rainfall (Figure 1) and warm, drying north-west winds. The resultant dry fuel covered thousands of hectares from Governors Bay to Tai Tapu. The steepness of the terrain made fighting the fire from the ground difficult so helicopters were used for protecting houses. Vegetation such as gullies of mature gorse (Ulex europaeus) burnt spectacularly and left a layer of ash covering the ground. These areas had no remaining ground cover and were, therefore, highly susceptible to erosion and ingress of weeds.

Land owners in Early Valley contacted Lincoln University for advice on how to regenerate the pastures and rapidly revegetate the bare gorse gullies before the onset of winter rainfall. Visual inspection in March confirmed that in pasture areas hundreds of subterranean clover (Trifolium subterraneum) seedlings had emerged from the burnt ground. Within days of the first post-fire rainfall, rhizomatous weeds such as Californian thistle (Cirsium arvense), yarrow (Achillea millefolium) and twitch (Elymus repens) emerged from the blackened earth. These were followed by recovery of cocksfoot and ryegrass (Lolium perenne) plants on the exposed grass slopes. Based on those observations, the decision was made not to oversow the pasture areas but to concentrate on controlling the regeneration of gorse in the gullies.

Burning is one of the easiest ways to remove mature gorse plants and is commonly used in forestry (MacCarter \& Gaynor 1980). However, the heat from fire usually stimulates germination of gorse seeds present in the soil (Zabkiewicz \& Gaskin 1978). This was apparent after the Port Hills fire where high populations of gorse seedlings quickly emerged from amongst the stumps of burnt mature gorse plants. Thus, the fire provided a unique opportunity for private land holders to control gorse. After the fire many of these lifestyle blocks had no fences, no water supply, and serious damage to houses with no immediate prospect of re-fencing. Thus, grazing stock could not be used as part of the gorse control solution.

Previous research has shown that gorse can be controlled as a seedling if it is out-competed for light (Moot et al. 2007). In glasshouse experiments, Ivens \& Mlowe (1980) and Davies et al. (2005) showed that perennial ryegrass competition could decrease the dry weight of gorse seedlings. However, neither trial resulted in the death of gorse seedlings because of perennial ryegrass competition. Based on these results perennial and Italian ryegrass (Lolium multiflorum) were used in this experiment exploiting their rapid establishment in cool autumn conditions (Moot et al. 2000).

The first aim of this study was to quantify the number of gorse seedlings that had regenerated from under the 


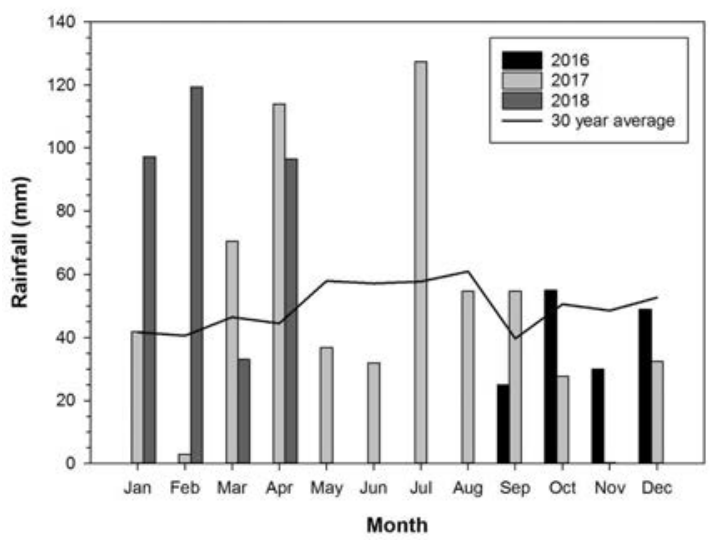

Figure 1 Monthly rainfall for 2016, 2017 and 2018, and a 30 year average for Broadfields, Lincoln, $9.5 \mathrm{~km}$ from the experimental site (NIWA 2018).

burnt gorse stand, and the second was to determine if oversown temperate pasture seeds could be used to decrease gorse seedling survival.

\section{Methods}

\section{Site and climate}

The experimental sites were located on a property off Early Valley Road on the Port Hills near Christchurch $\left(43^{\circ} 37^{\prime} \mathrm{S}, 172^{\circ} 34^{\prime} \mathrm{E}\right)$ in a gully that had been burnt in the recent fires. This left a scorched and bare area with no ground cover on 10 hectares of a north and south-facing gully. Before the fire, the gully had been covered in mature gorse bushes for over 30 years. On the 17th March 2017, the area was oversown (using a drone helicopter) with a seed mixture containing the equivalent of $10 \mathrm{~kg} / \mathrm{ha}$ Italian ryegrass, $5 \mathrm{~kg} / \mathrm{ha}$ perennial ryegrass, $5 \mathrm{~kg} / \mathrm{ha}$ subterranean clover and 2 $\mathrm{kg} / \mathrm{ha}$ cocksfoot. Rainfall data for the area are presented in Figure 1.

\section{Experiment 1: Gorse seedling control with oversown grass}

To determine the effect of oversowing the pasture mix on gorse seedling emergence, eight paired plots $(1.4 \mathrm{x}$ $1.9 \mathrm{~m}$ ) were marked across the south-facing hillside of the burnt gorse area. Before oversowing, a linen sheet was pegged out over one of each pair of the plots to prevent seed from falling on these areas. This created an oversown seeded plot and an unseeded control. Gorse seedlings were counted in 10 fixed $0.01 \mathrm{~m}^{2}$ quadrats within each plot, every 2 weeks, between 28th March and 26th May 2017. After this, counts were taken every 3 to 4 weeks depending on weather conditions until 21st March 2018.

\section{Experiment 2: Aspect and oversowing}

In the burnt gorse area two $20 \mathrm{~m}$ transects were established on the hillside with a north aspect and two south-facing, both at similar altitudes. All gorse, subterranean clover and grass seedlings were counted within a $0.01 \mathrm{~m}^{2}$ quadrat placed at $1 \mathrm{~m}$ intervals along the $20 \mathrm{~m}$ transect on the same dates as utilised for Experiment 1, until the 3rd October 2017.

Herbage mass was assessed in five $0.1 \mathrm{~m}^{2}$ randomly placed quadrats on both the north- and south-facing slopes on 28th November 2017, to determine botanical composition and yield. A subsample of herbage was separated into ryegrass, cocksfoot, clover, gorse, dead and weeds and dried at $60^{\circ} \mathrm{C}$ for $72 \mathrm{~h}$ before weighing.

\section{Experiment 3: Impact of Italian ryegrass shading}

The dominant oversown species that emerged was Italian ryegrass. It is therefore referred to as the control agent in all experiments. To quantify the impact of Italian ryegrass shading on gorse seedling establishment, gorse seedlings were dug up on 7th December 2017 from five randomly selected areas of bare ground, where Italian ryegrass had not established, and shaded areas, where Italian ryegrass was the dominant vegetation cover, on both the north and south-facing slopes. Approximately 30 plants were dug up from each area. In heavily shaded areas there were few if any gorse seedlings present. Gorse plants were transported to the laboratory, where 10 randomly selected plants from each area were washed and root and shoot length were measured. Gorse plants were oven-dried for 6 days at $60^{\circ} \mathrm{C}$ and weighed in groups of 10 to get an average weight for shaded and unshaded areas on both the north and south-facing slopes. Roots were also checked for signs of nodulation.

\section{Statistical analysis}

Statistical analyses were preformed using GENSTAT 18. For Experiment 1, a two sample 't'-test was used to determine if there was a difference in the number of gorse seedlings in seeded and unseeded control plots established on the south-facing slope. For Experiment 2 , a two sample ' $t$ '-test was also used to determine if there was a difference between the north- and southfacing slopes in gorse, grass and clover seedling establishment along the transects. For Experiment 3, a one way ANOVA was used to determine if there was a difference in gorse seedling dry weight and root and shoot lengths, between the shaded and unshaded plants sampled.

\section{Results}

Experiment 1: Gorse seedling control with oversown grass

In both treatments there were $\sim 100$ gorse seedlings $/ \mathrm{m}^{2}$ on 28th March 2017 (Figure 2). The number of gorse seedlings then increased to 680 plants $/ \mathrm{m}^{2}$ by 26th 


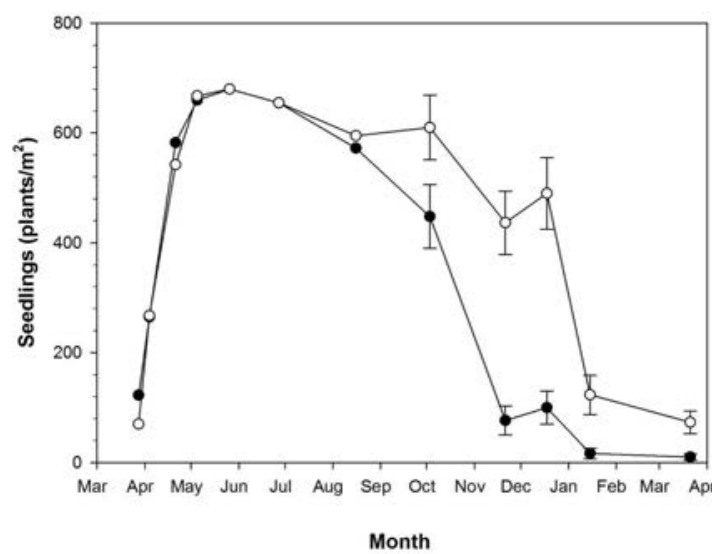

Figure 2 Number of gorse seedlings (plants $/ \mathrm{m}^{2}$ ) in plots with $(\bullet)$ or without $(O)$ oversowing of pasture seed on a south-facing slope of a burnt gorse gully on Port Hills, Canterbury. Error bars represent the standard error of the mean.

May 2017. By late-June the number of gorse seedlings began to decline. On the 3rd October 2017 there were fewer $(\mathrm{P}<0.001)$ gorse seedlings in the sown plots $(447$ plants $\left./ \mathrm{m}^{2}\right)$ than in the unsown control (610 plants/ $\mathrm{m}^{2}$ ), equating to a $52 \%$ reduction in gorse seedling density. The gorse seedling population continued to decline after October to $<100$ plants $/ \mathrm{m}^{2}$ in the sown plots compared with $\sim 480$ plants $/ \mathrm{m}^{2}(\mathrm{P}<0.001)$ in the unsown controls, and by 15th January 2018 there were $<20$ plants $/ \mathrm{m}^{2}$ in the oversown plots and 120 plants $/ \mathrm{m}^{2}$ in the controls $(\mathrm{P}=0.007)$. There were further reductions to 10 and 73 plants $/ \mathrm{m}^{2}$ in the sown and unsown plots, respectively, by the final measurement on 21st March $2018(\mathrm{P}=0.006)$.

\section{Experiment 2: Aspect and oversowing}

The herbage cut on 28th November 2017 showed the dominant ground cover in spring after oversowing was Italian ryegrass (control agent). It represented $60 \%$ of the $8.5 \mathrm{t} \mathrm{DM} /$ ha yield on the north-facing slope and $73 \%$ of the $10.6 \mathrm{t} \mathrm{DM} / \mathrm{ha}$ yield on the south-facing slope (Table 1). Perennial ryegrass was present, but to a lesser extent than the Italian ryegrass. There was no difference in gorse, weeds and dead material, which was mainly dead Italian ryegrass tillers, between the two aspects. The south side had more cocksfoot which made up $6.40 \%$ of the pasture compared with the north-facing slope where it was $<3 \%$. Subterranean clover showed the opposite trend with more on the north $(6.71 \%)$ than south side $(0.15 \%)$.

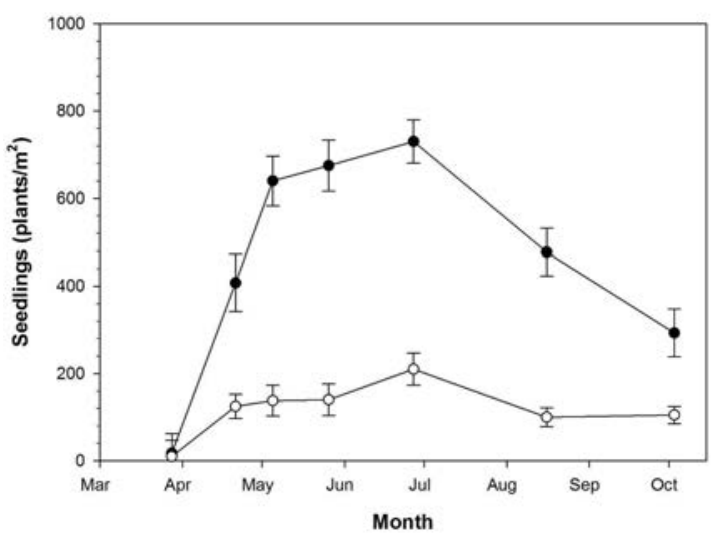

Figure $3 \quad$ Number of gorse seedlings (plants $/ \mathrm{m}^{2}$ ) on north $(O)$ and south $(\bullet)$-facing slopes during 2017 after oversowing a burnt gorse gully on the Port Hills, Canterbury. Error bars represent the standard error of the mean.

Similar numbers of gorse seedlings $(\mathrm{P}=0.420)$ were present on the south and north-facing slopes on 28th March 2017 (Figure 3). The number of gorse seedlings increased from fewer than 10 plants $/ \mathrm{m}^{2}$ on both slopes, with the increase being much higher on the south-facing slope. Three weeks later there were more $(\mathrm{P}<0.001)$ gorse seedlings on the south-facing slope (408 plants/ $\left.\mathrm{m}^{2}\right)$ than the north-facing slope $\left(125\right.$ plants $\left./ \mathrm{m}^{2}\right)$. This trend continued throughout the winter. Gorse seedlings reached their highest population for both slopes on the 27 th June 2017 , with more $(\mathrm{P}<0.001)$ gorse seedlings growing on the south $\left(730\right.$ plants $\left./ \mathrm{m}^{2}\right)$ than north-facing slope $\left(210\right.$ seedlings $\left./ \mathrm{m}^{2}\right)$. Gorse seedling populations then declined on both slopes, but the decline was more rapid on the south-facing slope. On the last measurement date, 3rd October 2017, there was 35\% more $(\mathrm{P}<0.002)$ gorse seedlings on the south than north-facing slope.

Five weeks after oversowing, 340 Italian ryegrass seedlings $/ \mathrm{m}^{2}$ had emerged on the south-facing slope compared with 75 seedlings $/ \mathrm{m}^{2}(\mathrm{P}<0.001)$ on the northfacing slope (Figure 4). From this point, the number of grass seedlings on the south-facing slope declined to $\sim 200$ plants $/ \mathrm{m}^{2}$ in June which was still $\sim 150$ plants $/ \mathrm{m}^{2}$ more $(\mathrm{P}<0.001)$ than on the north-facing slope, maintaining

Table 1 Yield and botanical composition of pasture sampled on north- and south-facing aspects on the 28th November 2017 after oversowing a burnt gorse gully on the Port Hills, Canterbury.

\begin{tabular}{lccccccc}
\hline \multirow{2}{*}{ Aspect } & $\begin{array}{c}\text { Yield } \\
\text { (kg DM/ha) }\end{array}$ & Ryegrass & Cocksfoot & Clover & Gorse & Weeds & Dead \\
\cline { 3 - 7 } & 8500 & 60.2 & 0.28 & 6.71 & 0.86 & 12.4 & 19.5 \\
North & 10500 & 72.8 & 6.40 & 0.15 & 1.04 & 2.48 & 17.1 \\
South & 0.074 & 0.074 & 0.015 & 0.001 & 0.734 & 0.150 & 0.410 \\
\hline P value & 0.074 &
\end{tabular}




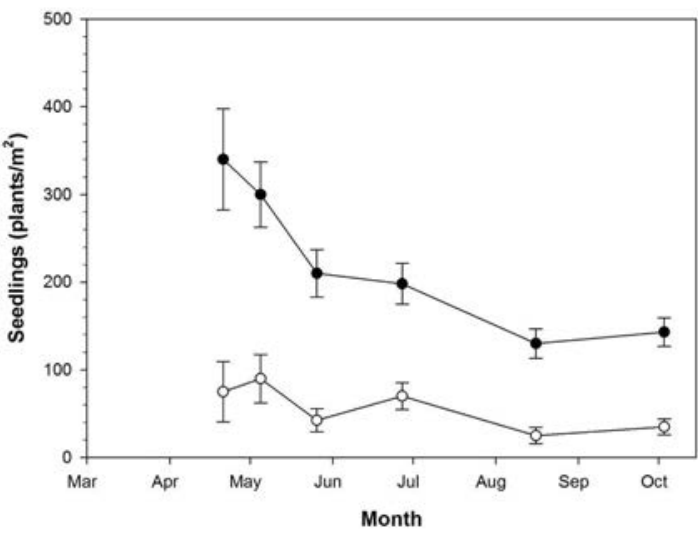

Figure 4 Number of Italian ryegrass seedlings (plants $/ \mathrm{m}^{2}$ ) on north $(O)$ and south $(\bullet)$-facing slopes during 2017 after oversowing a burnt gorse gully on the Port Hills, Canterbury. Error bars represent the standard error of the mean.

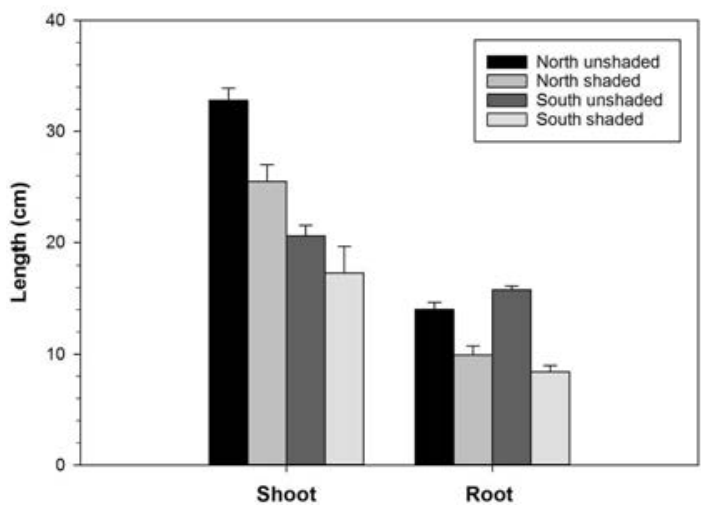

Figure 6 Shoot and root length of gorse seedlings grown with or without pasture shade on north and southfacing slopes on the 7th December 2017 after oversowing a burnt gorse gully on the Port Hills, Canterbury. Error bars represent the standard error.

these differences at the final measurement date.

The temporal pattern of establishment for subterranean clover was consistent with the grass, but populations were reversed with more subterranean clover seedlings emerged on the north-facing slope than the south-facing slope (Figure 5). At the first measurement there were $\sim 100$ subterranean clover seedlings $/ \mathrm{m}^{2}$ on the northfacing slope, but fewer $(\mathrm{P}<0.012)$ than 20 plants $/ \mathrm{m}^{2}$ on the south-facing slope. By October the numbers had declined to 45 plants $/ \mathrm{m}^{2}$ on the north-facing slope, still more $(\mathrm{P}<0.001)$ than the $5-15$ plants $/ \mathrm{m}^{2}$ found on the south-facing slope at each measurement date.

\section{Experiment 3: Impact of Italian ryegrass shading}

Gorse seedlings on the unshaded north-facing slope were taller (averaging $32.8 \mathrm{~cm}) \quad(\mathrm{P}<0.001)$ than seedlings $(20.6 \mathrm{~cm})$ on the unshaded south-facing slope

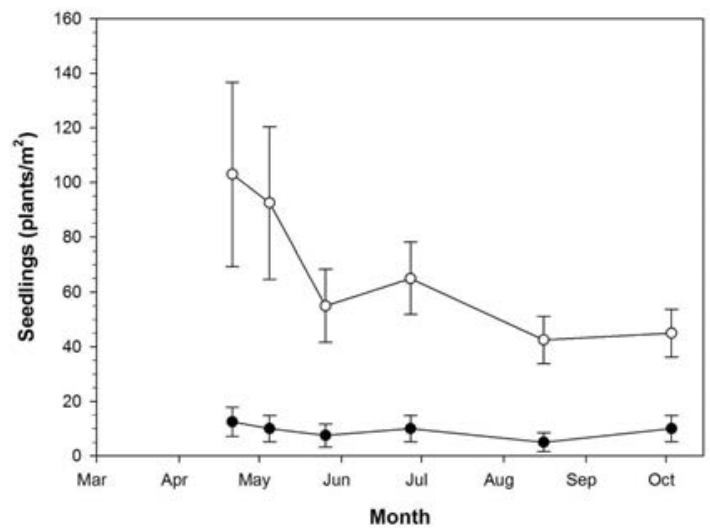

Figure 5 Number of subterranean clover seedlings (plants/ $\mathrm{m}^{2}$ ) on north $(\mathrm{O})$ and south $(\bullet)$-facing slopes during 2017 after oversowing a burnt gorse gully on the Port Hills, Canterbury. Error bars represent the standard error of the mean.

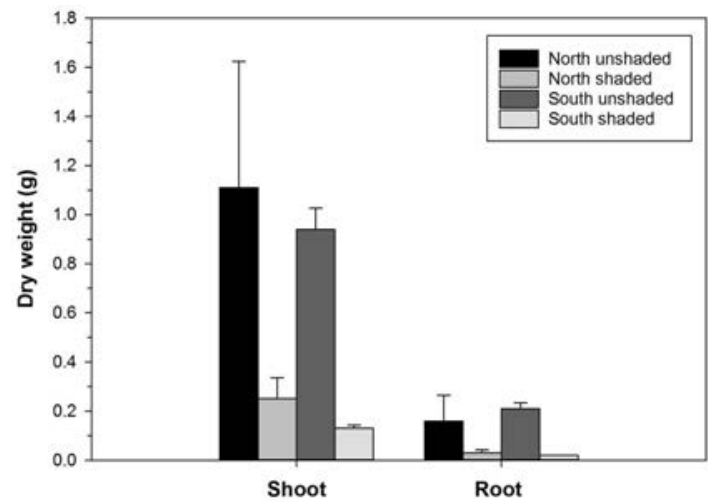

Figure 7 Shoot and root dry weight of gorse seedlings grown with or without pasture shade on north and south-facing slopes on the 7th December 2017 after oversowing a burnt gorse gully on the Port Hills, Canterbury.

(Figure 6). Shaded gorse seedlings on both slopes were reduced $(\mathrm{P}<0.001)$ with those on the south-facing slope being the shortest at $17.3 \mathrm{~cm}$.

Gorse seedlings growing in unshaded conditions had longer $(\mathrm{P}<0.001)$ roots than shaded gorse seedlings (Figure 6). On the south side, roots of unshaded seedlings $(15.8 \mathrm{~cm})$ were over double $(\mathrm{P}<0.001)$ the length of those grown under shade from Italian ryegrass.

When sampled on 7th December 2017, gorse seedlings grown on the north side with no shading had the highest $(\mathrm{P}=0.005)$ shoot dry weights of $1.11 \mathrm{~g} /$ plant (Figure 7). This was over four times heavier than shaded gorse seedlings. The shaded seedlings on the north side were taller than the unshaded seedlings on the south side (Figure 6), but unshaded seedlings were heavier as they were more mature and had begun to branch.

Unshaded seedlings also had higher $(\mathrm{P}=0.006)$ root 
dry weights than shaded seedlings (Figure 7). Visual observations confirmed that all gorse seedlings had roots that were nodulated, except a few small seedlings that appeared to be dying under the shaded treatments.

\section{Discussion}

One year after oversowing, shading from Italian ryegrass reduced the number of gorse seedlings to 10 plants $/ \mathrm{m}^{2}$ compared with $>70$ plants $/ \mathrm{m}^{2}$ in areas where there was no Italian ryegrass (Figure 2). The initial gorse seedling population in the unshaded plots shows the population potential created by the fire and indicates the rainfall conditions were conducive to survival of all seedlings had there been no intervention. The decline in seedling numbers in these control plots in November 2017 may have resulted from moisture stress due to a dry spring with only $83 \mathrm{~mm}$ rainfall compared with the average of $139 \mathrm{~mm}$ (Figure 1). In contrast, the oversown plots successfully controlled the gorse seedling populations that were reduced to 10 plants $/ \mathrm{m}^{2}$ by March 2018 (Figure 2).

The main period of gorse control appeared to occur in the spring after the autumn establishment and winter growth of the Italian ryegrass. This is shown by the lack of difference in the number of gorse seedlings between the shaded and unshaded control plots for up to 6 months after oversowing. The autumn sampling indicated continued germination of the gorse seedlings until a stable population occurred by May 2017. This remained at $>550$ seedlings $/ \mathrm{m}^{2}$ through winter. In October 2017 there was the first sign of population control via oversowing. The shaded plots had $>400$ plants $/ \mathrm{m}^{2}$ but this was 160 plants $/ \mathrm{m}^{2}$ fewer than the unseeded plots. However, by December 2017, there were still over 400 plants $/ \mathrm{m}^{2}$ in the control with fewer than 100 plants $/ \mathrm{m}^{2}$ in the shaded areas. This temporal pattern of decline was consistent with competition for light in the shaded plots. By spring 2017, the Italian ryegrass had produced a $40-50 \mathrm{~cm}$ tall canopy of 8-10 t DM/ha (Table 1) that completely over-topped the gorse seedlings. Previous research has shown that gorse seedlings are vulnerable to competition for light (Davies et al. 2005) and this method has previously been used to control them in ex-forestry land on the Canterbury Plains (Moot et al. 2007).

The suppression of the gorse population gave the land owner time to fix farm infrastructure and start grazing from November 2017, which was not possible immediately after the fire. However, in mature stands, a single bush may occupy a square metre so the potential still exists for the stand to re-establish from the population that remains in both the control and shaded areas.

Major reductions in the gorse population occurred in the shaded area through the summer as the site dried out. The Italian ryegrass would have assisted the rapid drying of the soil surface in spring, contributing to the death of gorse seedlings through moisture stress over summer. Gorse seedlings have a shorter and less extensive root system than ryegrass seedlings (Ivens \& Mlowe 1980). This disadvantages them when competing with ryegrass for water and nutrients. Gorse seedlings that were shaded by ryegrass had shorter shoots and roots (Figure 6) and lower dry weights (Figure 7) than unshaded seedlings, resulting in less photosynthesis by the gorse seedlings, and therefore less total dry matter to partition to roots and shoots. Davies et al. (2005) found perennial ryegrass sown at $15 \mathrm{~kg} /$ ha significantly reduced gorse seedling shoot dry weight from around $23 \mathrm{~g}$ in the control to $2 \mathrm{~g}$ in the ryegrass treatments. Gorse seedlings that had been shaded were still soft and less mature in December 2017 compared with unshaded seedlings, as spine development in gorse is delayed in low intensity light (Bieneik \& Millington 1968). This suggests the gorse seedlings in the pasture area will remain palatable to cattle and sheep for longer than in unshaded areas.

As expected, the oversowing in this experiment was inconsistent across the valley area. This resulted in areas of bare ground where Italian ryegrass competition was minimal and did not control the gorse seedlings. These areas either have to be resown or sprayed with appropriate herbicides to eliminate the remaining gorse seedlings.

Observations in March 2018, showed that no new gorse seedlings were germinating in areas of bare ground. This suggests that the majority of gorse seed in the seed bank germinated after the fire. Thus, the fire has provided an opportunity to eliminate gorse from the area providing that the remaining gorse seedlings are killed before they flower and further germination of seeds does not occur from the soil.

Higher populations of Italian ryegrass and gorse seedlings were found on the south-facing slope of the gully compared with the north-facing slope (Figures 3 and 4), likely due to the south-facing slopes having a higher soil moisture content (Radcliffe 1982) favouring initial establishment of the ryegrass. Similar results were found by White et al. (1972) who showed that oversown perennial ryegrass had better establishment by 6 months after sowing on the south-facing slope $\left(21.3\right.$ plants $\left./ \mathrm{m}^{2}\right)$ compared with the north-facing slope (4.7 plants $\left./ \mathrm{m}^{2}\right)$.

In contrast, subterranean clover established in higher numbers on the north-facing slopes (Figure 5) which was consistent with previous studies (Power 2007). It seems likely that the lower establishment of Italian ryegrass seedlings on this drier slope allowed more bare ground for the subterranean clover to establish. Subterranean clover is known as a fast establishing 
species (Moot et al. 2000) and this was evident in the burnt pasture areas where over 600 seedlings $/ \mathrm{m}^{2}$ emerged within 4 days of the first autumn rainfall postfire. Subterranean clover germinates and then forms a low growing rosette that is likely to be out-competed by the taller Italian ryegrass. It seems likely that the inclusion of the subterranean clover was not necessary for gorse seedling control in this situation. However, there were high subterranean clover populations in adjacent burnt pasture, but a lack of subterranean clover seed in the mature burnt gorse block. This suggests its introduction at the time of oversowing was prudent as the legume of choice for this environment, when permanent pasture development is the overall aim.

\section{Conclusions}

Italian ryegrass sown at $10 \mathrm{~kg} / \mathrm{ha}$ effectively controlled gorse seedling regeneration on a burnt gorse block.

There was minimal establishment of other sown species but their impact should be assessed over time, particularly if the Italian ryegrass does not regenerate.

\section{ACKNOWLEDGEMENTS}

The authors acknowledge the landowners, D. Shields and $\mathrm{B}$. Hayden, for allowing access to the site at a time of considerable disruption.

\section{REFERENCES}

Bieniek, M.E.; Millington, W. 1968. Thorn formation in Ulex europaeus in relation to environmental and endogenous factors. Botanical Gazette 129: 145-150.

Davies, J.; Ireson, J.; Allen, G. 2005. The impact of gorse thrips, ryegrass competition, and simulated grazing on gorse seedling performance in a controlled environment. Biological Control 32: 280-286.

Ivens, G.; Mlowe, F. 1980. A study of competition between seedlings of gorse (Ulex europaeus L.) and perennial ryegrass (Lolium perenne L.) by means of a replacement series experiment. Weed Research 20 : 183-191.

MacCarter, L.; Gaynor, D. 1980. Gorse: a subject for biological control in New Zealand. New Zealand Journal of Experimental Agriculture 8: 321-330.

Moot, D.J.; Mills, A.; Marshall, A.J., Edwards, G. 2007. Lucerne establishment sequences to maximise weed control in ex-Pinus radiata L. plantations. Proceedings of the New Zealand Grassland Association 69: 99-105.

Moot, D.J.; Scott, W.R.; Roy, A.M.; Nicholls, A.C. 2000. Base temperature and thermal time requirements for germination and emergence of temperate pasture species. New Zealand Journal of Agricultural Research 43: 15-25.

Power, D.R. 2007. Defining the sub clover zone on Mt Grand, Central Otago. Masters thesis, Lincoln University, Canterbury, New Zealand.

Radcliffe, J. 1982. Effects of aspect and topography on pasture production in hill country. New Zealand Journal of Agricultural Research 25: 485-496.

White, J.G.; Meijer, G.; Langer, R.H.M. 1972. Oversowing grasses on sunny and shady faces. Proceedings of the New Zealand Grassland Association 34: 139-146.

Zabkiewicz, J.; Gaskin, R. 1978. Effect of fire on gorse seeds. Proceedings of the 31 st New Zealand Weed and Pest Control Conference: 47-52. 